\title{
ANALISIS KESALAHAN KONSEP MATEMATIKA SISWA DALAM MENYELESAIKAN SOAL TRIGONOMETRI KELAS X TKJ SMKN 1 GEMPOL TAHUN PELAJARAN 2016/2017
}

\author{
Tifaniar Andriani ${ }^{1}$, Ketut Suastika ${ }^{2}$, Nyamik Rahayu Sesanti ${ }^{3}$ \\ ${ }^{1}$ Program Studi Pendidikan Matematika, Universitas Kanjuruhan Malang \\ tifaniar.a@gmail.com \\ ${ }^{2}$ Program Studi Pendidikan Matematika, Universitas Kanjuruhan Malang \\ suastika@unikama.ac.id \\ ${ }^{3}$ Program Studi Pendidikan Matematika, Universitas Kanjuruhan Malang \\ nyamik@unikama.ac.id
}

\begin{abstract}
Abstrak: Penelitian ini bertujuan untuk mengetahui kesalahan konsep matematika yang dilakukan siswa kelas X TKJ di SMK Negeri 1 Gempol dalam menyelesaikan soal trigonometri, dan sekaligus juga untuk mengetahui penyebabnya. Penelitian ini menggunakan pendekatan deskriptif kualitatif dengan subjek penelitian meliputi siswa kelas X TKJ 3 di SMK Negeri 1 Gempol. Teknik pengumpulan menggunakan tes dan wawancara. Teknik analisis data yang digunakan adalah reduksi data hasil tes dengan wawancara. Hasil penelitian menunjukkan bahwa kesalahan konsep matematika yang sering dilakukan oleh siswa yaitu siswa tidak mampu menyajikan konsep dalam berbagai representasi matematis. Diketahui penyebabnya adalah dikarenakan faktor internal dari siswa seperti pemahaman siswa yang masih kurang, lupa konsep yang sudah diajarkan dan lain-lain.
\end{abstract}

Kata Kunci : Analisis, Kesalahan Konsep, Soal Trigonometri

\section{Pendahuluan}

Matematika merupakan ilmu yang mampu mengasah kemampuan logika berpikir dan analisis. Johnson dan Rising dalam Erman Suherman, dkk (2003:17) mengungkapkan "matematika adalah pola berpikir, pola mengorganisasikan, pembuktian yang logis. Selain itu, matematika adalah bahasa yang menggunakan istilah yang didefinisikan secara cermat, jelas, dan akurat, representasinya dengan simbol yang padat, lebih berupa bahasa simbol mengenai ide dari pada mengenai bunyi". Oleh karena itu, matematika merupakan salah satu mata pelajaran yang dipelajari oleh semua siswa dari tingkat SD sampai SMA dan bahkan juga di perguruan tinggi. Kompetensi-kompetensi ini diperlukan tak lain agar siswa dapat memiliki kemampuan memperoleh, mengelola, dan memanfaatkan informasi, salah satunya dalam menyelesaikan soal matematika. Namun, banyak orang yang memandang matematika sebagai salah satu bidang studi yang paling sulit.

Matematika selalu identik dengan konsep dan siswa akan selalu dituntut untuk memahami konsep-konsep yang ada pada matematika. Cucu (2010) menyatakan bahwa konsep adalah ide atau gagasan yang dibentuk dengan memandang sifat-sifat yang sama dari sekumpulan eksemplar yang cocok. Nasution (2008) mengartikan bahwa apabila seseorang dapat menghadapi benda atau peristiwa sebagai suatu kelompok, golongan, kelas, atau kategori maka orang tersebut sudah belajar konsep. Kamus Besar Bahasa Indonesia mendefinisikan pengertian konsep adalah gambaran mental dari objek, proses, atau 
apapun yang ada di luar bahasa, yang digunakan oleh akal budi untuk memahami hal-hal lain. Akal manusia memiliki peranan yang penting untuk memahami sebuah konsep.

Penguasaan konsep dalam matematika diperlukan untuk memecahkan masalah dalam matematika sebagai wujud aplikasi dari konsep tersebut. Pemecahan masalah adalah bagian yang sering dirasa sulit oleh siswa karena diperlukan keterampilan berhitung, penguasaan konsep yang matang, kemampuan menginterpretasikan bahasa yang baik, dan lain-lain supaya siswa tidak melakukan kesalahankesalahan dalam mengerjakan soal matematika. Jenis-jenis kesalahan yang sering dilakukan oleh siswa dalam menyelesaikan soal-soal matematika menurut Subanji dan Mulyoto yang diungkapkan Rosita (2007) antara lain kesalahan interpretasi bahasa, siswa seringkali melakukan kesalahan dalam menyatakan bahasa sehari-hari dalam bahasa matematika. Hal tersebut dikarenakan banyaknya simbol-simbol, grafik dan tabel sehingga membuat siswa melakukan kesalahan tersebut; kesalahan teknis, dalam aspek ini siswa sering melakukan kesalahan-kesalahan perhitungan atau komputasi dalam mengerjakan soal-soal; kesalahan konsep, seringkali siswa melakukan kesalahan dalam menentukan atau menerapkan rumus untuk menjawab suatu masalah. Siswa melakukan kesalahan di dalam penggunaan teorema atau rumus yang tidak sesuai dengan kondisi prasyarat berlakunya rumus tersebut atau tidak menuliskan teorema.

Jenis-jenis kesalahan lainnya yang dilakukan oleh siswa dalam menyelesaikan soal-soal matematika antara lain: kesalahan menggunakan data, dimana dalam hal ini siswa sering tidak menggunakan data yang seharusnya dipakai dalam menjawab pertanyaan yang ada. Siswa juga melakukan kesalahan dalam memasukkan data ke variabel dan menambah data yang tidak diperlukan dalam menjawab suatu masalah; kesalahan penarikan kesimpulan, hal ini menjadi suatu kesalahan karena dalam mengambil kesimpulan tanpa didasari alasan pendukung yang benar dan sering tidak sesuai dengan penalaran logika; kesalahan imajinasi merupakan kesalahan dan kekeliruan siswa dalam imajinasi ruang (spasial) dalam dimensi-dimensi tiga yang berakibat salah dalam mengerjakan soal-soal matematika; kesalahan prasyarat merupakan kesalahan dan kekeliruan siswa dalam mengerjakan soal matematika karena bahan pelajaran yang sedang dipelajari siswa belum dikuasai, dan kesalahan tanggapan yaitu kekeliruan dalam penafsiran atau tanggapan siswa terhadap konsepsi, rumus-rumus dan dalil-dalil matematika dalam mengerjakan soal matematika (Rosita, 2007).

Kesalahan yang lebih sering terjadi pada siswa saat mengerjakan soal adalah kesalahan pada konsep atau biasa disebut miskonsepsi. Fowler (dalam Suparno, 2005) memandang "miskonsepsi sebagai suatu pengertian yang tidak akurat terhadap konsep, penggunaan konsep yang salah, klasifikasi contoh-contoh yang salah, kekacauan konsep-konsep yang berbeda, dan hubungan konsep-konsep yang tidak benar". Konsep awal yang tidak dapat diterima siswa dengan baik dapat mengakibatkan miskonsepsi yang berlanjut. Jika miskonsepsi siswa tidak segera ditangani maka akan membuat siswa mengalami kesulitan-kesulitan belajar dan bermuara pada rendahnya prestasi belajar siswa.

Seperti halnya pembelajaran matematika di SMKN 1 Gempol, dijumpai siswa yang masih kesulitan 
dalam menerima materi yang diajarkan. Hal ini menyebabkan siswa mengalami kesulitan dalam menyelesaikan soal yang diberikan sehingga kesalahan dalam menyelesaikan soal pun tidak dapat dihindari. Kesalahan inilah yang menyebabkan rendahnya nilai yang diperoleh siswa tak terkecuali pada materi trigonometri, khususnya pada sub bab penggunaan aturan sinus dan cosinus, yang membutuhkan pemahaman konsep yang tepat dan ketelitian yang tinggi.

Berdasarkan wawancara dengan guru mata pelajaran matematika kelas $\mathrm{X}$ TKJ SMKN 1 Gempol, ternyata masih banyak siswa yang mengalami kesulitan dalam mengerjakan soal trigonometri terutama pada penggunaan aturan sinus dan cosinus, yang dikarenakan oleh beberapa hal seperti kesulitan dalam menentukan data apa yang harus digunakan oleh siswa dalam pengerjaan yang sistematis, sehingga banyak kesalahan yang dilakukan. Kita ketahui bersama bahwa penggunaan aturan sinus dan cosinus secara benar itu penting dalam pembelajaran matematika karena menuntut siswa untuk dapat berpikir secara kritis, logis, sistematis dan teliti, yang mana hal ini dapat menjadi landasan bagi siswa untuk membangun pola pikir yang baik dalam menyelesaikan soalsoal, khusunya soal-soal matematika.

Menurut Rangkuti (2009:14-16) analisis adalah "kegiatan memahami seluruh informasi yang terdapat pada suatu kasus untuk mengetahui permasalahan apa yang sedang terjadi, lalu memutuskan tindakan apa yang harus segera dilakukan untuk memperoleh penyelesaian atau pemecahan masalah". Analisis pada penelitian ini adalah peneliti memeriksa dan memahami pekerjaan siswa berdasarkan indikator yang sesuai dengan penelitian ini. Kesalahan konsep tidak akan terjadi jika kemampuan siswa dalam memahami konsep sudah benar. Menurut Sanjaya (2009), yang dimaksud pemahaman konsep adalah kemampuan siswa yang berupa penguasaan sejumlah materi pelajaran, dimana siswa tidak sekedar mengetahui atau mengingat sejumlah konsep yang dipelajari, tetapi mampu mengungkapan kembali dalam bentuk lain yang mudah dimengerti, memberikan interprestasi data dan mampu mengaplikasikan konsep yang sesuai dengan struktur kognitif yang dimilikinya. Sebagaimana yang dikemukakan Ruseffendi (2006:156) bahwa terdapat banyak siswa yang setelah belajar matematika, tidak mampu memahami bahkan pada bagian yang paling sederhana sekalipun, banyak konsep yang dipahami secara keliru sehingga matematika dianggap sebagai ilmu yang sukar, ruwet, dan sulit.

$$
\text { Zulkardi (2003:7) menyatakan }
$$

bahwa "mata pelajaran matematika menekankan pada konsep". Artinya dalam mempelajari matematika siswa harus memahami konsep matematika terlebih dahulu agar dapat menyelesaikan soal-soal dan mampu mengaplikasikan pembelajaran tersebut di dunia nyata. Mengingat pentingnya pemahaman konsep tersebut, menurut Hiebert dan Carpenter (dalam Dafril: 2011), bahwa pengajaran yang menekankan kepada pemahaman mempunyai sedikitnya lima keuntungan, yaitu: a) pemahaman memberikan generatif, b) pemahaman memacu ingatan, c) pemahaman mengurangi banyaknya hal yang harus diingat, d) pemahaman meningkatkan transfer belajar, e) pemahaman mempengaruhi keyakinan siswa.

$$
\text { Menurut Mu'awinah (2010), }
$$
penyebab dari resistennya sebuah kesalahan konsep karena setiap orang membangun pengetahuan persis dengan pengalamannya sendiri. Indikator yang digunakan dalam penelitian ini diadopsi 
dari Tim PPPG Matematika 2005:86 (dalam Dafril, 2011) yang berjumlah lima yaitu sebagai berikut: a) tidak mampu menyatakan ulang konsep; b) tidak mampu mengklasifikasikan objek-objek menurut sifat-sifat tertentu; c) tidak mampu memaparkan konsep secara berurutan; d) tidak mampu menyajikan konsep dalam berbagai bentuk representasi matematis; e) tidak mampu mengaplikasikan konsep atau algoritma pemecahan masalah.

Dari pemaparan di atas, sangat diperlukan analisis kesalahan konsep siswa dalam menyelesaikan soal Trigonometri. Tujuannya adalah agar siswa tidak melakukan kesalahan konsep secara berkelanjutan. Seperti yang kita ketahui bahwa konsep adalah pondasi dasar dalam matematika. Sama halnya dalam materi trigonometri khususnya pada subbab aturan sinus dan cosinus yang juga membutuhkan pemahaman konsep sebagai dasarnya. Jika siswa tidak mampu menguasai konsep secara benar maka keberhasilan dalam belajar tidak akan bisa dicapai dengan maksimal. Selain itu, siswa perlu mengetahui letak kesalahan mereka dalam pemahaman sebuah konsep.

\section{Metode Penelitian}

Penelitian ini merupakan penelitian deskriptif kualitatif yang bertujuan untuk mengetahui letak kesalahan konsep matematika dan penyebab kesalahan tersebut dilakukan. Subjek dalam penelitian ini adalah siswa kelas X TKJ 3 SMK Negeri 1 Gempol. Teknik pengumpulan data yang digunakan dalam penelitian ini adalah dengan tes dan wawancara. Tes yang diberikan merupakan tes individu yang harus dikerjakan oleh siswa, setelah itu akan dilakukan wawancara pada beberapa siswa yang dipilih sesuai dengan kategori pada penelitian ini. Analisis data dalam penelitian ini adalah reduksi data, penyajian data dan penarikan kesimpulan. Reduksi data dilakukan dengan tiga tahap yitu 1) merekam hasil wawancara dan mencatat hasil wawancara tersebut, 2) memeriksa catatan dengan mendengarkan ulang rekaman wawancara, 3) hasil catatan diketik sesuai dengan informasi yang dibutuhkan. Penyajian data pada penelitian ini ada dua bentuk yaitu hasil jawaban siswa dan catatan hasil wawancara dengan siswa. Untuk penarikan kesimpulan yaitu dengan mengkroscek jawaban siswa saat tes dengan jawaban siswa saat diwawancara sehingga dapat diketahui kesalahan konsep lengkap dengan penyebabnya. Pengecekan keabsahan data dalam penelitian ini menggunakan teknik triangulasi sumber dan teknik. Tahaptahap yang dilakukan dalam penelitian ini adalah perencanaan, pelaksanaan, dan analisis data.

\section{Hasil dan Pembahasan Hasil}

Acuan yang digunakan adalah indikator-indikator mengenai kesalahan konsep matematika yang digunakan dalam penelitian. Berikut adalah hasil dari setiap indikator yang digunakan,

a. Tidak mampu menyatakan ulang kembali konsep, siswa yang melakukan kesalahan ini sebanyak 20 siswa dari jumlah keseluruhan 40 siswa.

b. Tidak mampu mengklasifikasikan objek-objek berdasarkan sifat-sifat tertentu, siswa yang melakukan kesalahan ini sebanyak 19 siswa dari jumlah keseluruhan 40 siswa.

c. Tidak mampu memaparkan konsep secara berurutan, siswa yang melakukan kesalahan ini sebanyak 20 siswa dari jumlah keseluruhan 40 siswa. 
d. Tidak mampu menyajikan konsep dalam berbagai bentuk representasi matematis, siswa yang melakukan kesalahan ini sebanyak 33 siswa dari jumlah keseluruhan 40 siswa.

e. Tidak mampu mengaplikasikan konsep atau algoritma pemecahan masalah, siswa yang melakukan kesalahan ini sebanyak 19 siswa dari jumlah keseluruhan 40 siswa.

\section{Pembahasan}

1. Tidak mampu menyatakan ulang konsep

Siswa lebih sering mengerjakan soal tanpa menuliskan konsep yang digunakan. Penyebabnya karena memang siswa sudah terbiasa mengerjakan secara instan tanpa menuliskan prosedurnya secara lengkap. Kesalahan ini dilakukan pada semua soal tes yang telah diberikan.

2. Tidak mampu mengklasifikasikan objek-objek menurut sifat-sifat tertentu

Banyak siswa yang mengalami kebingungan dalam menentukan konsep yang akan digunakan karena tidak mampu mengklasifikasikan objek yang diketahui.

3. Tidak mampu memaparkan konsep secara berurutan

Siswa banyak yang salah dalam memaparkan konsep bahkan ada yang tidak memaparkan konsep sama sekali. Penyebab siswa melakukan hal tersebut karena siswa mengerjakan dengan cara cepat tanpa mengetahui proses yang sebenarnya.

4. Tidak mampu menyajikan konsep dalam berbagai representasi matematis

Dari subjek yang sudah diwawancarai, diketahui penyebab siswa melakukan kesalahan ini adalah siswa tidak terbiasa mengerjakan soal dengan menuliskan apa yang diketahui dan apa yang ditanyakan sebelumnya.
5. Tidak mampu mengaplikasikan konsep atau algoritma pemecahan masalah

Berdasarkan data yang diperoleh dari wawancara dengan beberapa subjek, dapat diketahui penyebab siswa melakukan hal ini dikarenakan siswa kebingungan saat memakaikonsep untuk diaplikasikan pada penyelesaian suatu soal. Pemahaman pada soal yang dirasa kurang juga menjadi salah satu penyebab siswa melakukan kesalahan konsep pada indikator ini.

\section{Kesimpulan}

1. Berdasarkan analisis hasil tes yang digunakan untuk mengetahui kesalahan konsep matematika siswa, diketahui siswa melakukan kesalahan konsep pada indikator-indikator yang digunakan dalam penelitian ini.

2. Berdasarkan wawancara dengan siswa yang terpilih sesuai dengan tingkat kelompok, diperoleh penyebab siswa melakukan kesalahan konsep rata-rata berasal dari dirinya sendiri (faktor internal) seperti lupa, tidak memahami konsep dengan benar, tidak memahami maksud soal, hanya sekedar menghafal konsep bukan memahaminya.

\section{SARAN}

1. Siswa diharapkan agar lebih memperhatikan konsep yang telah diajarkan karena pemahaman konsep sangatlah penting. Ketika siswa paham konsep maka tidak akan terjadi kesalahan konsep. Mengingat bahwa konsep dalam matematika adalah dasar dalam matematika itu sendiri.

2. Guru diharapkan agar lebih menekankan lagi pemahaman konsep kepada siswa. Memberikan pengarahan dalam pengerjaan soal secara runtut sesuai dengan indikator agar tidak terjadi kesalahan konsep 
matematika siswa dalam mengerjakan soal.

3. Peneliti lain diharapkan mampu menyempurnakan penelitian ini karena penelitian ini memiliki kekurangan yaitu hasil tes dari beberapa siswa masih belum murni sesuai dengan kemampuan mereka sendiri.

\section{DAFTAR RUJUKAN}

Adelyna, Rosita. 2007. Analisis Kesalahan Siswa Kelas VIII SMP Negeri 18 Semarang dalam Menyelesaikan Soal Matematika pada Pokok Bahasan Lingkaran dengan Panduan Kriteria Watson. Skripsi. Fakultas Matematika dan Ilmu Pengetahuan Alam. UNNES

Cucu Suhana. 2010. Konsep Strategi Pembelajaran. Bandung: Refika Aditama.

Dafril,A. 2011. Pengaruh Pendekatan Konstruktivisme Terhadap Peningkatan Pemahaman Matematika Siswa. (Prosiding). PGRI Palembang. Tidak diterbitkan.

Erman Suherman, dkk. (2003). Strategi Pembelajaran Matematika Kontemporer. Bandung : Jica

Mu'awinah, Ajnihatin. 2010. Miskonsepsi Siswa dalam Menyelesaikan Soal-
Soal Trigonometri Kelas XI SMA Negeri 1 Ungaran Tahun Ajaran 2009/2010. Skripsi. Fakultas Keguruan dan Ilmu Pendidikan. Universitas Kristen Satya Wacana.

Nasution. 2008. Berbagai Pendekatan dalam Proses Belajar dan Mengajar. Cetakan keduabelas. Bumi Aksara. Jakarta.

Paul Suparno. 2005. Miskonsepsi dan Perubahan Konsep Pendidikan Fisika. Jakarta: Grasindo.

Rangkuti, Freddy. 2009. Strategi Promosi yang Kreatif dan Analisis Kasus Integrated Marketing Communication. Jakarta: PT. Gramedia Pustaka Utama.

Ruseffendi, E.T.. 2006. Pengantar Kepada Membantu Guru Mengembangkan Kompetensinya dalam Pengajaran Matematika untuk Meningkatkan CBSA. Bandung: Tarsito.

Sanjaya, Wina. 2009. Strategi Pembelajaran Berorientasi Standar Proses Pendidikan. Jakarta: Kencana Prenada Media Group.

Zulkardi. 2003. Pendidikan Matematika di Indonesia : Beberapa Permasalahan dan Upaya Penyelesaiannya. Palembang: Unsri. 